DOI 10.38129/ Ann.Yur.Ist.2020.4.1.29

УДК 616-001.4-001.5: 616-001.445

\title{
РАНИ ТА СПОСОБИ ЇХННЬОГО ЛІКУВАННЯ В ЕПОХУ СЕРЕДНЬОВІЧЧЯ ТА РАННЬОГО ВІДРОДЖЕННЯ
}

\author{
ОКСАНА ОБУХОВСЬКА (Львів, Україна) *
}

Рана $є$ явищем доволі повсякденним. Достатньо лише одного необережного руху, щоб пошкодити шкіру і побачити як на ній проступають червоні краплі крові. Звичайно це здається дрібничкою, проте навіть невелике поранення може призвести до потрапляння в організм інфекції, i чим більшою є рана, тим серйознішими можуть бути ऑї наслідки. Проте ще декілька століть тому причин боятися виникнення ран було значно більше. Недогляд і погане лікування легко могли призвести якщо не до смерті, то до обов' язкової втрати однієї з кінцівок, та й самих ситуацій, в яких можна було отримати травму було більше.

На думку Дж. Класпера, основні принципи лікування ран, особливо завданих на полі бою, у період Середніх віків не зазнали істотних змін з епохи Античності. Вони полягали у припиненні кровотечі, запобіганні потраплянню інфекції та допомозі в зціленні рани. При цьому збереглися задокументовані суперечки про спосіб перев'язування ран та лікувальну роль гною. На думку того ж автора, серед лікарів переважала думка, що рана повинна бути промита вином, однак подальші дії щодо обробки рани викликали дискусії. Так, існувало два основних способи зцілення рани: або «закрити» iï за допомогою швів, або залишити рану відкритою, очікуючи природного загоювання ${ }^{1}$. В останньому випадку рану покривали жиром чи використовували абсорбуючі пов' язки², тим самим сприяючи Виникненню гною, бо саме його чимала кількість лікарів вважала головною ознакою загоювання. Палким противником теорії цілющої властивості гною був хірург Теодор Лука. Він наполягав на тому, що «не потрібно, як писали Роджер і Роланд, так як багато їхніх учнів навчали, $і$ як всі сучасні хірурги сповідувати те, що гній має утворюватися в ранах. Жодна помилка не може бути більшою за иую. Подібна

\footnotetext{
${ }^{1}$ Wounds in the Middle Ages / ed. by Anne Kirkham, Cordelia Warr. - Farnham: Ashgate, 2014. - P. 17.

2 Ibidem. P. 18.
} 
практика насправді перешкоджае природі, продовжуе захворювання, запобігає склеюванню $і$ затвердінню рани». Так, медик пишався шрамом, який виник як наслідок заживання рани, без використання будь-яких мазей. Тому він був проти використання припарок та масел, в той час як порошки, він вважав, занадто висушували рану³.

Іншою поширеною методикою для лікування ран було припікання. Суть його полягала у тому, що розжарений металевий стержень прикладали до пошкодженої частини тіла. На ділянках, де кістка близько прилягає до шкіри, залишалися сліди від цієї процедури, тому ії можна ідентифікувати за допомогою знайдених решток. Зокрема, під час розкопок в Осло були знайдені рештки людини, захоронені при церкві св. Клеменса, які містили невеликі заглиблення. Останні П. Холк визначає як ознаки припікання 4 (Додаток $€$ ).

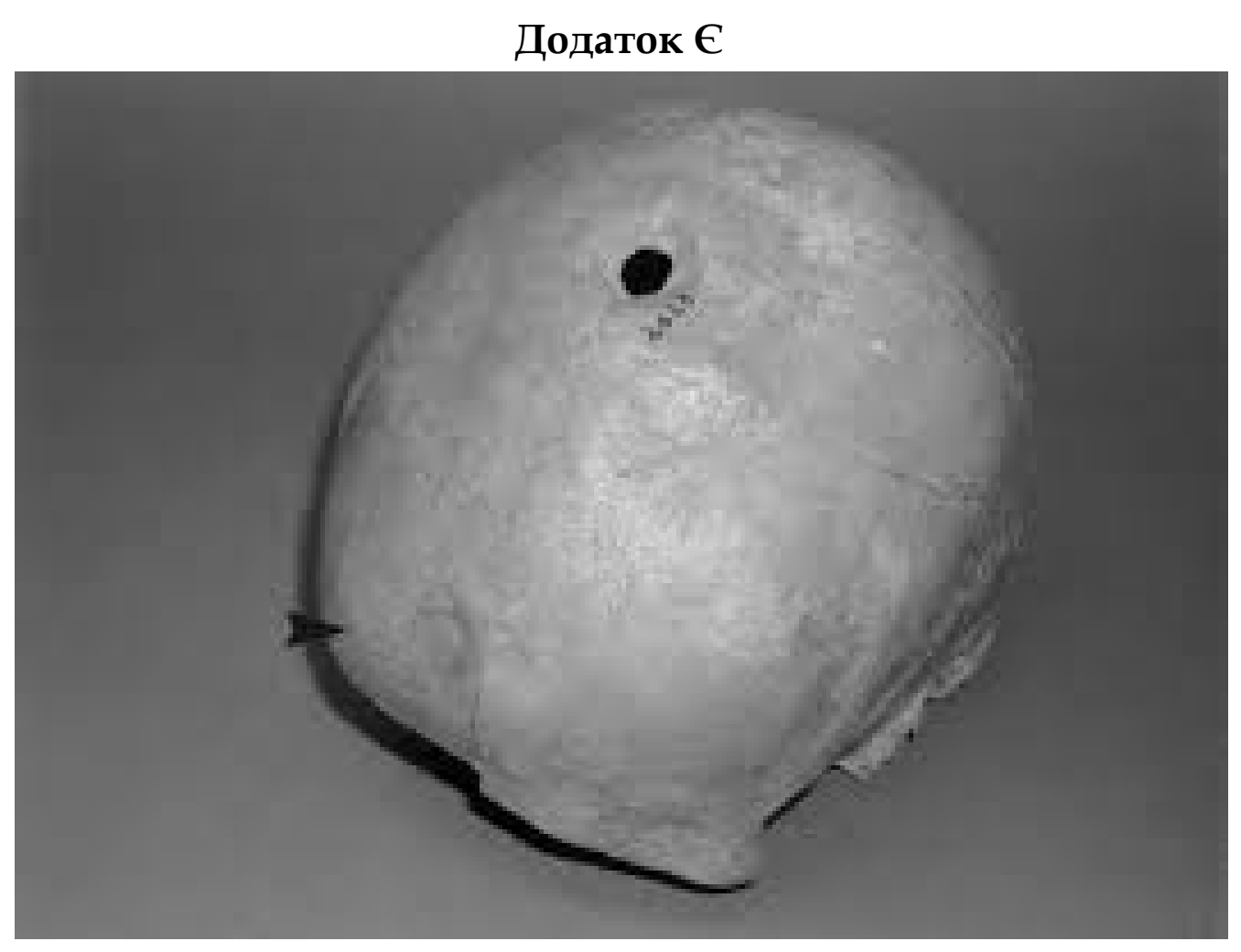

Деформація поверхні черепа розпеченим залізом.

Взято з: Holck P. Two 'Medical' Cases from Medieval Oslo / / P. Holck / Int. J. Osteoarchaeol. 2002. - 12. - P. 170.

${ }^{3}$ Walsh James J. Ugo da Lucca/ James J. Walsh // The Linacre Quarterly: - 1938. - Vol. 6: No. 1, Article 4. - P. 14-15.

${ }^{4}$ Holck P. Two 'Medical' Cases from Medieval Oslo // P. Holck / Int J Osteoarchaeol. 2002. - 12. - P. 169-170. 
Смирну (мірру, смолу) для лікування ран почали використовувати ще в давньому Сгипті, i сучасні дослідження підтверджують, що вона мала антибактеріальні властивості, знешкоджуючи у тому числі й стафілококову аурею, найпоширенішу причину зараження ран у військових ${ }^{5}$. Ще Пліній Старший, у свою чергу, наголошував на лікувальних властивостях смоли оливкового дерева, що сприяла загоюванню рани без іiі попереднього зшивання, а у розділі про лікувальні властивості рослин згадує вчений і траву, назва, якої залишається невідомою, тому він і називає іiі анонімом. Ії він рекомендував використовувати при пораненнях, змішавши із водою, пити отриману суміш при пораненні грудей, передсердя та кровохарканні 6 . Але все ж, зазвичай, рану спочатку промивали вином або оцтом. Оцет $\epsilon$ ефективним способом боротьби 3 pseudomonas - бактеріями типу протеобактерій, а вино - ефективним проти бактерій холери та кишкової палички.

Також використовували суміші із порошку, виготовленого 3 мушлі равлика, мідної руди, крейди, холодної води, оцту або вина7. Зокрема, за порадою Павла з Егіни, фекалії тварин, наприклад, екскременти коня або осла, у суміші з іншими речовинами використовували для припинення кровотечі8, а овечі відходи обсмажені з медом - для лікування карбункул 9 . Цілком можливо, що флора бактерій одного виду може гальмувати патологічні бактерії людини, тому таке перев' язування несло певну користь ${ }^{10}$. Поточні дослідження використання срібла у перев'язуванні бойових ран нагадують стародавнє використання металевих сполук для лікування. Це могли бути сполуки міді та свинцю. Ці метали зазвичай застосовували 3 вологими речовинами, такими як мед (який має антисептичні властивості через вміст глюкозооксидази, що призводить до виробництва антибактеріальних глюконолактонів та пероксиду водню). Крім того, мед має ще одну користь у доанестетичний час, оскільки він не прилипає до ран, i

${ }^{5}$ Wounds in the Middle Ages / ed. by Anne Kirkham, Cordelia Warr. - P. 22.

6 Подосинов А. Римские географические источники: Помпоний Мела и Плиний Старший // А. В. Подосинов. М. В. Скржинская. - Москва, 2001.

7 Wounds in the Middle Ages / ed. by Anne Kirkham, Cordelia Warr. - P. 23.

8 Adams F. The seven books of Paulus AEgineta : translated from the Greek: with a commentary embracing a complete view of the knowledge possessed by the Greeks, Romans, and Arabians on all subjects connected with medicine and surgery / Francis Adams. - London: Printed for the Sydenham society, 1844-1847. - P. 9.

${ }_{9}^{9}$ Гостре гнійне запалення глибоких шарів шкіри і підшкірної клітковини.

${ }^{10}$ Adams F. The seven books of Paulus AEgineta : translated from the Greek. - P. 77. 
таким чином, полегшує зміну перев' язки, що робить їі менш болючою11.

Особливо важко медикам доводилося під час лікування ран, спричинених бойовими діями. Так, в античні часи для вилучення стріли з тіла використовували «ложку Діоклеса» (spoon of Diocles), винайдену Діоклесом 3 Карустоса (Karystos) (Додаток А). Після того як рану розширювали, «ложкою Діоклеса» просувалися по осі стріли, доки не знаходили їі наконечник. Чашки ложки закривали наконечник стріли, одночасно прикриваючи колючі гачки, якщо такі були. Такий пристрій дозволяв витягнути стрілу, не викликаючи додаткових травм.

\section{Додаток А}

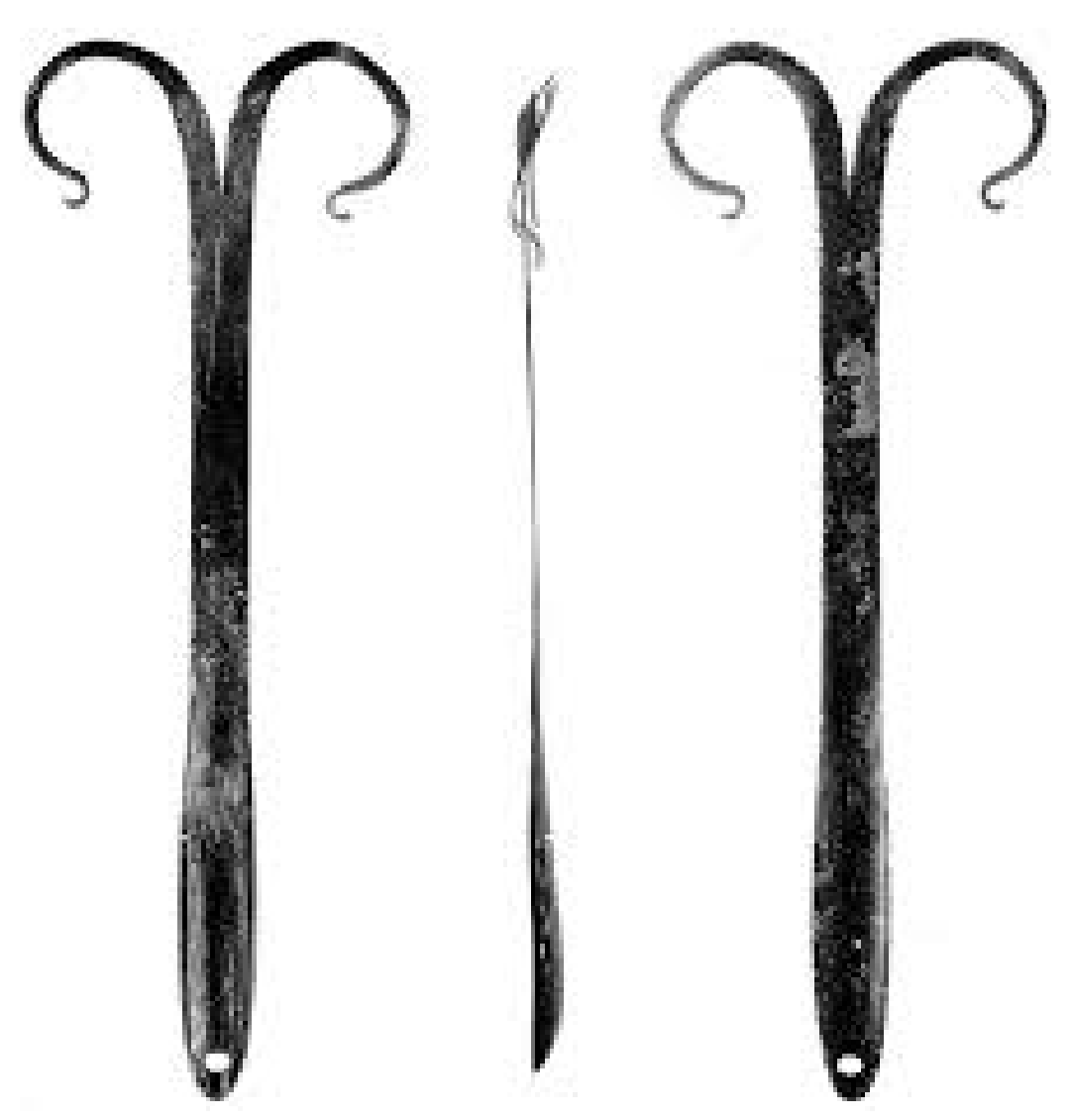

«Ложка Діоклеса», взято з: Karger B. Arrow Wounds: Major Stimulus in the History of Surgery / Bernd Karger, M.D., Hubert Sudhues, M.D., Bernd Brinkmann, M.D. // World Journal of Surgery. - Vol. 25, No. 12, December 2001. - P. 1551.

В часи Середньовіччя винахід Діоклеса не використовувався, хоча кількість поранених стрілами не зменшувалося.

${ }^{11}$ Wounds in the Middle Ages / ed. by Anne Kirkham. - P. 24. 
Загальновідомо, що англійський король Річард I Левове Серце (11571199) був поранений арбалетним болтом у плече під час облоги замку Шалю і загинув через гангрену, яка була викликана раною.

\section{Додаток Б}

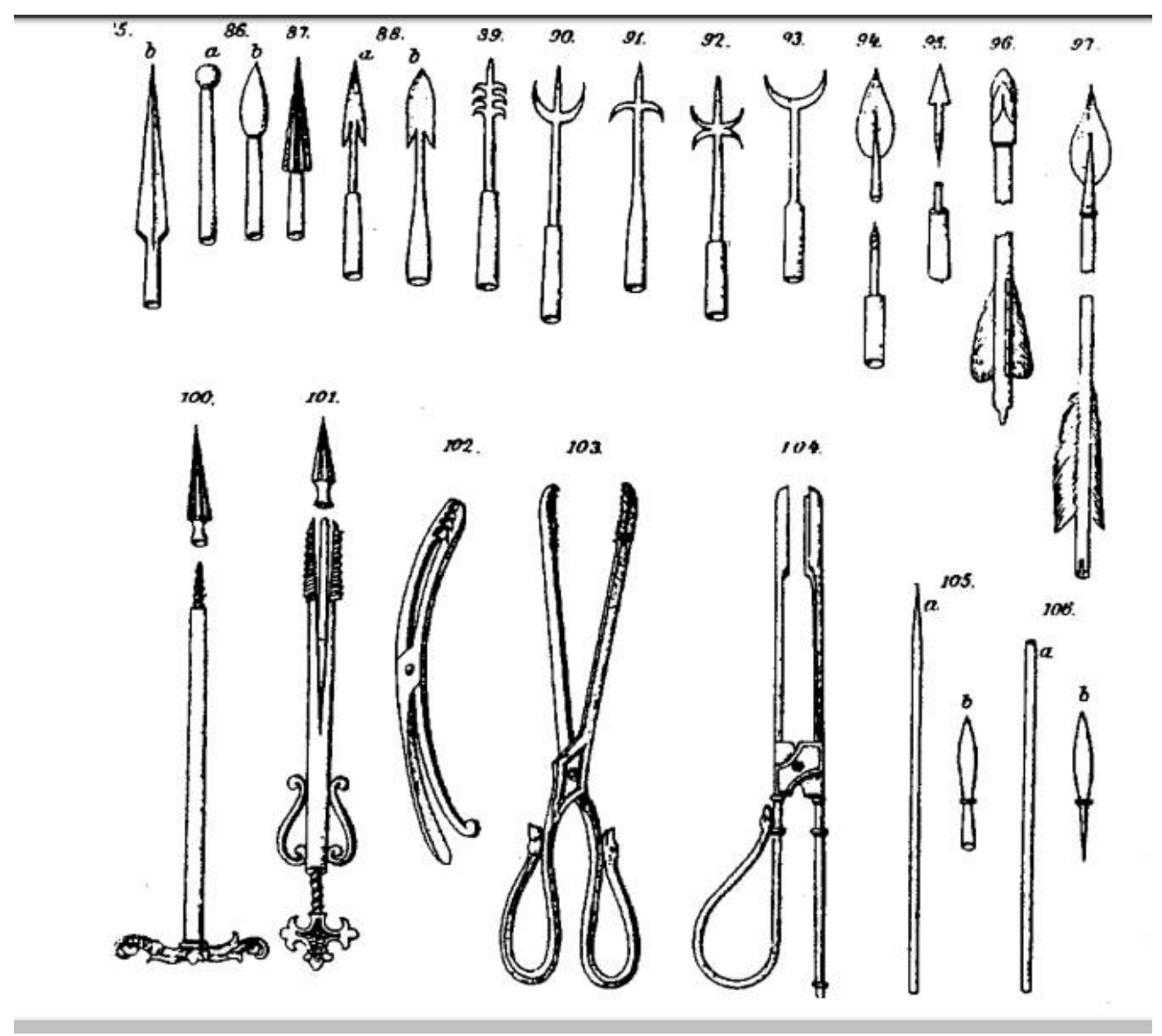

Ілюстрація із Giovan Andrea dalla Croce з зображенням різних типів наконечників стріл, відомих у XVI ст. (зверху) і колекція інструментів для вилучення стріл (знизу). Інструменти під числами 100 і 101 призначені для вкручування у відрізаний вал, під числами 105, 106 для видалення окремих наконечників для стріл. Взято з: Karger B. Arrow Wounds: Major

Stimulus in the History of Surgery / Bernd Karger, M.D., Hubert Sudhues, M.D., Bernd Brinkmann, M.D. / / World Journal of Surgery. - Vol. 25, No. 12, December 2001. - P. 1552.

Генріх фон Пфольспеунт (Heinrich von Pfolspeundt) - німецький лицар, член Тевтонського ордену, у XV ст. для вилучення стріли 3 тіла діяв наступним чином: він відпилював вісь стріли на декілька сантиметрів над раною, залишаючи решту на 8-14 днів у тілі, доки рана не наповнювалася 
гноєм і стрілу можна було б $з$ легкістю витягнути ${ }^{12}$.

Збільшення рани зазвичай не практикували, а витягували залишки стріли за допомогою залізних знарядь, зондів з різьбленими закінченнями для викручування у залишену частину осі чи щпиці (Додаток Б).

На противагу Генріху фон Пфольспеунту, Генрі де Мондевіль радив витягувати стрілу одразу. У своїх працях, він описував спосіб витягування міцно всаджених стріл, за допомогою арбалету. Стрілу прив' язували шнурком до закріпленого арбалету, 3 якого згодом стріляли ${ }^{13}$ (Додаток В). Завдяки Мондевілю деякі хірурги XV i XVI ст. надавали перевагу негайному вилученню стріл, не чекаючи виникнення гною, і серед них варто виділити Джованні де Віго (Gioanni Da Vigo), Яна Тагаулта (Jean Tagault) і Джован' Андреа делла Кроце (Giovan'Andrea dalla Croce) ${ }^{14}$. При подібних операціях вони часто застосовували анестезію, опис якої ми зустрічаємо у роботі Гюї де Шоліака 15: "Деякі хірурги призначають ліки, такі як опіум, сік гриба зморшка їтівного, блекоти чорної, мандрагори лікарської, плющуа, болиголова плямистого, салату синього, які відправляли пацієнтів до сну ${ }^{16}$. Потім вони виконують операцію17». Зазвичай, зазначені рослини кип'ятили у воді чи вині, після чого пацієнту давали випити отриману рідину. Існував також і спосіб, коли вологу повинна була всмоктати у себе губка, а пацієнт мусив вдихати пари 3 неї. Проведений у сучасних умовах експеримент 3 губкою, викликав у

12 Pfolsprundt H. Buch der Bündth-Ertznei von, Bruder des deutschen Ordens / Heinrich von Pfolsprundt; heraugegeben Heinrich Haeser, Albrecht Theodor Middeldorpf. - Berlin: Drug und Verlag von Georg Reimer, 1868. - 179 s.

${ }^{13}$ Chirurgie de maître Henri de Mondeville, chirurgien de Philippe le Bel, roi de France, composée de 1306 à 1320 / avec des notes, une introduction et une biographie par E. Nicaise, avec la collaboration du Dr Saint-Lager et de F. Chavannes. - Paris: Alcan, 1893. - 904 s. - Режим доступу до електронної версії документа: https://gallica.bnf.fr/ark:/12148/bpt6k288444.pdf.

${ }^{14}$ Karger B. Arrow Wounds: Major Stimulus in the History of Surgery / Bernd Karger, M.D., Hubert Sudhues, M.D., Bernd Brinkmann, M.D. // World Journal of Surgery. - Vol. 25, No. 12, December 2001. - P. 1550-1555.

${ }_{15}$ Walsh James J. Medieval Medicine / James J. Walsh. - A. \& C. BLACK, LTD. SOHO SQUARE, LONDON, W.C. Library of Alexandria, 1920. - P. 120.

16 Через вміст у них алкалоїдних сполук, які фізіологічно і фармакологічно дуже активні, часом отруйні або діють як наркотики.

17 Chauliac G. Chirurgia magna / Guy de Chauliac; hrsg. Laurent Joubert. - Darmstadt: Wissenschaftliche Buchgesellschaft, 1976. 
піддослідних лише сонливість, хоча цілком можливо, що у Середньовіччі застосовували якийсь спеціальний вид губок, склад яких не зазначався у джерелах ${ }^{18}$. Але анестезію при хірургічному втручанні використовували не всі, зокрема Ганс фон Герсдорф стверджував, що провів близько однієї чи двох сотень ампутацій без використання опіуму чи якогось іншого анестетика ${ }^{19}$.

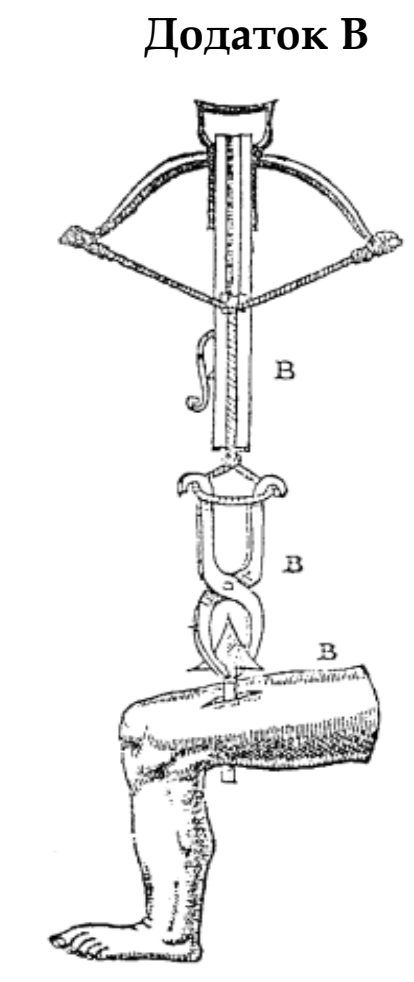

Вилучення стріли за допомогою арбалету, спосіб запропонований Генрі де Мондевілем на початку XIV ст.

Взято 3: Karger B. Arrow Wounds: Major Stimulus in the History of Surgery / Bernd Karger, M.D., Hubert Sudhues, M.D., Bernd Brinkmann, M.D. // World Journal of Surgery. - Vol. 25, No. 12, December 2001. - P. 1553.

Головні зміни у хірургї XVI ст. були наслідком збільшенням кількості вогнепальної зброї.

У медицині це явище призвело до збільшення чисельності переломів. Холодна зброя, зазвичай, ранила лише плоть, а якщо і ламала кістку, то лише

${ }_{18}$ Mitchell P. D. Anatomy and surgery in Europe and the Middle East during the Middle Ages / P. D. Mitchell // Perdicoyianni-Paleologou, H. (ed) Anatomy and Surgery from Antiquity to the Renaissance. - Amsterdam: Adolf Hakkert, 2016. - P. 309-324.

19 Gersdorff H. Feldbuch der Wundarznei / Hans von Gersdorff. - Darmstadt: Wissenschaftliche Buchgesellschaft, 1967. 
в одному місці та на вузькій ділянці. Випадки складних переломів були настільки рідкісними, що навіть Гіппократ рекомендував ампутацію пораненої кінцівки при наступних показниках: «Випнуту кістку потрібно відпиляти через наступні причини: якщо не можна ї̈ вставити на своє місце, якщо трішки не вистачає, щуоб вона увіӥшла, або можна ї̈ витягти, якщо вона буде недоречна і може поранити м'язи з будь-якої сторони, якщо буде спричиняти труднощі при відновленні і якщзо буде оголена, то і в таких випадках слід провести видалення. Чи будуть відпиляні інші кістки чи ні, не важливо, тому що потрібно знати, кістки, які абсолютно позбавляються м'яса $і$ сохнуть, відокремлюються uілком ${ }^{20}$ ». Особливі труднощі виникають при відкритих переломах стегна та плечей: «якщо ти вправиш кістку, то зазвичай з'являються судоми, а без вправляння - чихоманки гострі, жовчні, з гикавкою $i$ гангреною» 21, ситуація настільки складна, що «батько медицини» радить лікарю взагалі не втручатися: «найкраще всього иього уникнути, якщуо є можливість піти з честю, так як надії небагато, а небезпек навпаки: якщо не вправиш (кістку), покажеш себе немайстерним, а якщуо вправиш, то приведеш хворого скоріше до смерті, ніж до спасіння» 22 .

Вогнепальна зброя, у свою чергу, має таку силу удару, яка легко спричиняє перелом кісток більше, ніж в одному місці. Рання зброя стріляла свинцевими кулями вагою у половину унції. Початкова швидкість кулі була невеликою, а сама куля була дуже нестабільною у польоті 23 . Свинцева куля має властивість розлітатися на частини, що спричиняло роздроблення кісток ${ }^{24}$. Зіткнувшись 3 подібними ранами лікарі зазвичай використовували старий і перевірений метод - ампутацію. Адже вогнепальна рана, залишена без догляду також становила для пораненого серйозну загрозу. Куля, просікаючи тіло людини, заносила в рану шматочки одягу та шкіри.

Військові хірурги зіткнулися із проблемою, яким чином видалити зруйновану кулю з людського тіла.

Поширеною технологією стало попереднє розширення рани i

${ }^{20}$ Гиппократ. Сочинения / Гиппократ; Пер. В. И. Руднева, комм. В. П. Карпова. Москва: Биомедгиз, 1936. - С. 572.

21 Там само.

22 Гиппократ. Сочинения. / Гиппократ; Пер. В. И. Руднева, комм. В. П. Карпова. Москва: Биомедгиз, 1936. - С. 573.

23 Hopkinson D. A. W. Firearm Injuries / D. A. W. Hopkinson, T. K. Marshal // British Journal of Surgery 54, no 4 (May 1967). - P. 344-353.

${ }^{24}$ Gabriel Richard A. Between Flesh and Steel: A History of Military Medicine from the Middle Ages to the War in Afghanistan. - P. 32. 
діставання кулі пальцями чи за допомогою нестерилізованих щипщів. Це неухильно призводило до збільшення ризику інфікування. Крім того, теорія похвального гною викликала цілий ряд спроб сприяння виникненню гною, за допомогою бруду та подібних речовин. Велика чисельність смертей, викликана цими фактами, призвела до появи думки, що рани від кулі отруєні, а тому їхню дію необхідно нейтралізувати припіканням і киплячою олією.

Вперше нова доктрина з'явилася в Александрійській армії, де їі впровадив хірург Хієронімус Бруншвігс (Hieronymus Brunschwig), описавши у праці «Книга хірургіï (1497 р.). У ній він радив витягувати кулю щипщями, а для пришвидшення виникнення гною - змащувати рану жирним беконом 25 . Доктрина набула широкого розголосу завдяки впливу особистого лікаря папи Юліуса II (Julius II) Джованні де Віго (1460-1520), який опублікував їі у своєму трактаті в 1514 р. 26 Сам же де Віго для полегшення болю рекомендував використовувати розтоплене масло, ячмінну воду або воду 3 додаванням земляних черв'яків та скипидар з яєчним жовтком, якими необхідно було змазувати рану вже після процедури 27. Зрозуміло, що таке лікування не могло полегшити біль, навпаки, сприяло ускладненню лікування.

Однією 3 найперших великих робіт, присвячених вивченню вогнепальних ран стала «De sclopetorum sive archibusorum vulneribus», Альфонсіо Ферріо (лат. Alfonsio Ferrio), яка вийшла у Римі в 1552 році28. Вивчаючи способи вилучення куль з людського організму, Ферріо розробив інструмент, обладнаний кільцем для витягування снарядів, діаметр кільця відповідав розміру кулі, що мало б дозволити легко схопити та витягнути ії.

${ }^{25}$ Giovanni Vigo. Prima pars practice in chirurgia: Practica in arte chirurgica copiosa ... / Giovanni Vigo. - in aedibus Iacobi Myt..., sumptib[us]... Vince[n]tii de Portonariis, 1519. Режим доступу до електронної версії документа: https://bildsuche.digitalesammlungen.de/index.html?c=viewer\&bandnummer $=$ bsb00026460\&pimage $=11 \& v=2 p \&$ nav $=\& l=$ de

${ }^{26}$ Forrest R. D. Development of Wound Therapy from the Dark Ages to the Present / Robert D. Forrest / / Journal of the Royal Society of Medicine. - (April 1982). - № 75. P. 269.

27https://ia800207.us.archive.org/14/items/primaparspracti00goog/primaparspracti00go og.pdf

${ }^{28}$ Billroth Th. Historical Studies on the Nature and Treatment of Gunshot Wounds from the Fifteenth Century to the Present Time / Theodor Billroth // Yale J Biol Med. - 1931 Dec; 4(2). - P. 131. 
Такий пінцет отримав назву «альфонсин» (Додаток Г) ${ }^{29}$. В деяких місцях поранення Ферріо вважав пов' язку абсолютно необхідною, при цьому, будучи прихильником теорії про лікувальні властивості гною, він передбачив те, що утримування рани мало дозволяти гною витікати без перешкод. Кровопускання він радив проводити лише для сильних пацієнтів, за винятком поранених в груди, та вважав не потрібним до третього дня, адже до того часу рана ще залишалася отруєною. Але здійснювати вищезгадану процедуру потрібно було до сходу сонця, коли повітря було прохолодним. Відкрита, при складних переломах, кістка, за рекомендаціями Ферріо не має бути пошкоджена хірургом і навіть деякі кулі медик «дозволяє» залишати в тілі. (Авероес стверджував, що свинець має певну спорідненість до плоті). При ранах біля кінцівок суглобів радив перев'язки та повне знерухомлення тіла, теплі ванни, які складалися з 10 до 1 порції олії до білого оцту, масаж та щоденний рух, який не викликав би болю. Інструменти, необхідні для розширення країв рани повинні бути розроблені самим хірургом, щоб забезпечити індивідуальний підхід до кожної рани ${ }^{30}$.

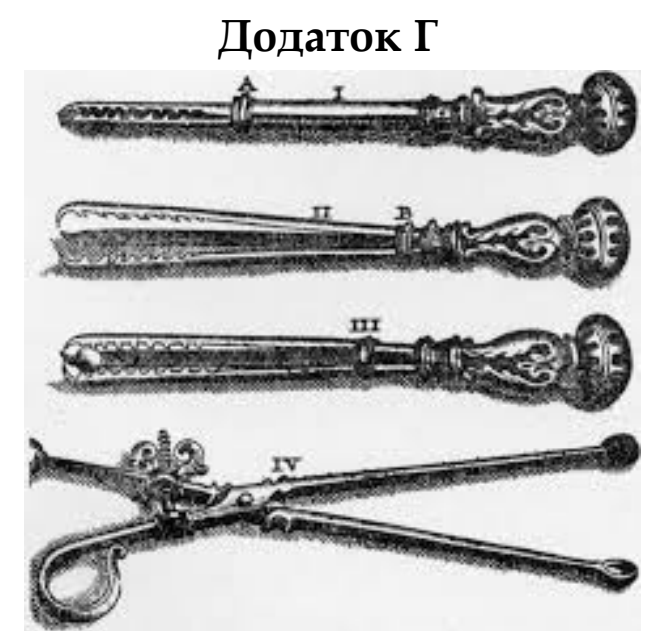

«Альфонсин» Альфонсіо Ферріо. Взято з: Billroth Th. Historical Studies on the Nature and Treatment of Gunshot Wounds from the Fifteenth Century to the Present Time / Theodor Billroth / / Yale J Biol Med. - 1931 Dec; 4(2). - P. 118-148.

Хоча з отрутою продовжували боротися тисячі військових лікарів, були й такі, які не сприймали нову доктрину i підходили до лікування вогнепальних ран з огляду на власний досвід і спостереження. Особливо серед них виділяються Амбруаз Паре (1510-1590), Ганс фон Герсдорф (1455-1529) та

\footnotetext{
${ }^{29}$ Ibidem. P. 132.

${ }^{30}$ Ferrio A. De Sclopetorum sive archibusorum vulneribus libri tres, corollarium de sclopeti ac similium tormentorum pulvere / Alfonso Ferrio. - M. Bonhomme, 1553 - P. 123.
} 


\section{Парацельс (1493-1541).}

Зокрема, Ганс фон Герсдорф у праці «Польова книга хірургії ран» (1517 р.) $)^{31}$ стверджував, що вогнепальні рани не були отруйними і радив їх лікувати, промивши спочатку рану теплою олією 3 насіння коноплі задля вимивання пороху із рани. Кулю виймав за допомогою різних інструментів, після чого на рану наносив так звану «єгипетську мазь», яка складалася 3 меду, оцту, зелені й галунів (мінералів). Італійський хірург Бартоломео Маггі (Bartholomeo Maggi) (1516-1552) написав трактат про вогнепальні рани, який був опублікований в рік його смерті (1552 р.) У ньому він стверджував, що вогнепальні поранення насправді не $є$ отруєними 32 , оскільки пороху в організм потрапляло небагато, а той порох, що залишався на шкірі, був абсолютно не шкідливим. Він засудив суворі методи лікування де Віго $і$ радив якнайmвидше видаляти кулі 33. Якщо з'явилася гангрена в якості наслідку процесу запалення, Маггі рекомендував негайну ампутацію, під час чого радив відрізати м'які тканини набагато вище місця ураження ${ }^{34}$.

Леонардо Боталло (Leonardo Botallo), лікар французького короля Карла IX, у своєму трактаті про стрільбу з вогнепальної зброї (1560р.) виступав проти безрозсудного розширення ран, рекомендованого Віго, а в процесі вилучення кулі пропонував використовувати укорочені щипці ${ }^{35}$. Пінцет i «альфонсин» вважав ненадійними для вилучення куль. У випадках дроблення кісток, розривання плоті та великих судин кінцівок рекомендував ампутацію. Потрапляння кулі в череп вважав смертельним, проте у випадках, коли рану спричиняли лише їі уламки, рекомендував витягнути видимі частини. Поранення грудної клітини також вважалося невиліковним у випадках пошкодження легень, серця, перикарда (зовнішньої оболонки серця) ${ }^{36}$.

Масове використання пороху i часті вибухи гармат призвели до збільшення чисельності опіків. Найпоширенішим способом лікування обпалених

${ }^{31}$ Gersdorff H. Feldbuch der Wundarznei / Hans von Gersdorff.

32 Garrison F. H. Notes on the History of Military Medicine / Fielding Hudson Garrison. Hildeshein New York: Georg Olms Verlag, 1970. - P. 113.

${ }_{33}$ Maggi B. De vulnerum sclopetorum, et bombardarum curatione tractatus / Bartolomeo Maggi. - B. Bologna, Italy, 1552.

34 Billroth Th. Historical Studies. - P. 134.

35 Garrison F. H. Notes on the History of Military Medicine. - P. 113.

36 Botallo L. De curandis vulneribus sclopettorum / Botallo, Leonardo. - Francofurti ad Moenum: apud Georgium Corvinum, 1575. Електронна версія документу: https://archive.org/details/ ARes7851608. 
частин тіла були різні овочі та тваринні жири, щзо зазвичай призводили до виникнення пухириів та рубиів. Ще одним способом лікування було використання чорнил, що містять танінову кислоту, яка є ефективною анти-пухириевою речовиною ${ }^{37}$. Паре використовував пасту 3 подробленої цибулі та солі, що зменшувала кількість опіків - спосіб який, за переказами, йому підказала стара сільська жінка. Зазначимо, що пізніше радянські солдати використовували подібні способи лікування у 1945 p. 38

Амбруаз Паре, народжений у Франщї, в Бур-Ерсан, самостійно здобув освіту хірурга та зміг стати головним війсъковим хірургом при чотиръох монархах, а також - автором Важливих медичних трактатів, найкращий із яких иее «Метод лікування вогнепальних ран» (1545 р.).

Паре винайшов багато хірургічних інструментів, ввів у використання штучні кінцівки та очі, імплантацію штучних зубів, намагався організувати медичне забезпечення звичайних воїнів ${ }^{39}$. Иого власний досвід показав, що традиційне використання припікання і киплячої олії приносить значно більше болю і смертей, ніж зцілення. Ось як він сам згадує отриманий досвід: «Я був у иееи час прісноводним воїном; я ще не бачив ран, зроблених вогнепальною зброєю. Це правда, щуо я прочитав у першій книзі Джованні де Віго (...) у восьмому розділі, щзо рани, отримані від вогнепальної зброї - отруєні, через дію пороху; $і$ для їхнъого лікування він пропонує вам припалити їх киплячою олією з додаванням невеликої кількості меліси. I, щоб не помилитися, до того як використати вказану олію, знаючи, щуо ие принесе великий біль моїм пацієнтам, я запитав інших хірургів, щзо вони робили під час перших перев'язок; вони наливали вказану олію, перед тим добре прокип'ятивши їі, у рану (...); тому я сміливо робив те, щуо мені сказали. Нарешті, моя олія скінчилася і мені довелося використовувати настоянку із жовтка, трояндової олї і скипидару. Вночі я не міг спокійно спати, боячись, щзо знайду поранених, яким я не припік рану мертвими через отруту; це змусило мене з самого ранку відвідати їх. (...) Я виявив, що ті, на кому я застосував свою настоянку мали невеликий біль, а їхні рани не містили ознак запалення чи набряків, вони досить добре відпочили вночі; інших, яких я лікував киплячою олією, знайшов у гарячці, з великим болем та набряками по краях рани. Тоді я вирішив ніколи більще не опікати біднх

37 Sigerist Henry E. Ambrose Pares Onion Treatment of Burns / Henry E. Sigerist // Bulletin of the History of Medicine 15, no 2 (February 1944). - P. 143.

38 Garrison. Notes of History - P.48.

${ }^{39}$ Gabriel Richard A. Between Flesh and Steel: A History of Military Medicine from the Middle Ages to the War in Afghanistan / Richard A. Gabriel. - Washington, D. C.: Potomac Books, 2013. - P. 33. 
ююдей з вогнепальними ранами»40.

Паре повернув у практику античний метод попереднього зв'язування кінцівки вище місця поранення перед ампутацією - процедуру, яку не використовували 3 часів Цельса. Він закликав повторно очищати рану, використовував червоне вино в якості антисептика, перев'язував рани ${ }^{41}$. Для вилучення кулі з рани він використовував інструмент «рот ящірки» (фр. bec de Lezard) (Додаток Д), який складався з трубки, що закінчувалася двома зубчатими лопатками, одна з них рухалася за допомогою пружини, та «дзьоб папуги» (фp. bec de perroquet) (Додаток E), який нагадував металеві щипці, де одна частина рухалася та закріплювала кулю за допомогою гвинта42. Загалом, його методи лікування були прогресивними, та спрямованими насамперед на піклування про пацієнтів.

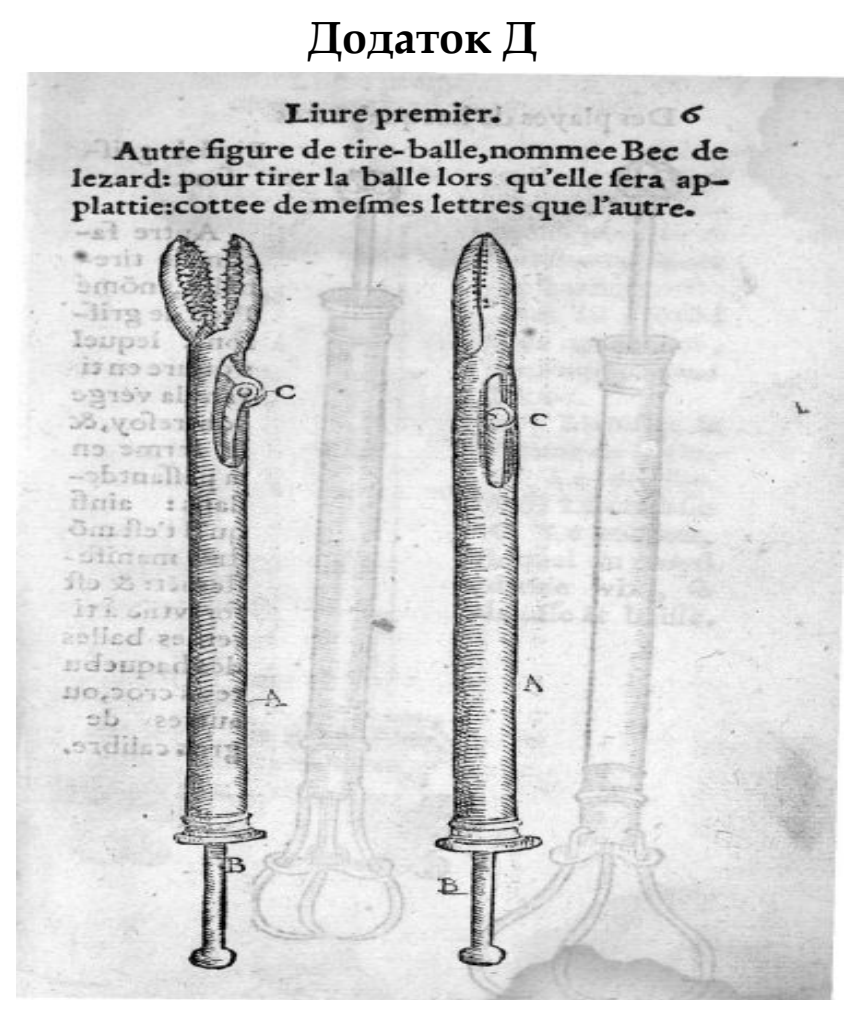

Хірургічний інструмент Амбруаза Паре «Вес de lezard». Взято 3: Paré Ambroise. Dix livres de la chirurgie avec / Ambroise Paré. - Paris: Jean Le Royer, 1564.

\footnotetext{
40 Paré A. A Surgeon in the Field // Ambroise Pare / The Portable Renaissance Reader: eds. James Bruce Ross and Mary Martin McLaughlin. - New York, Viking Penguin, 1981. P. 558-563.

${ }^{41}$ Sigerist Henry E. Ambrose Pares Onion Treatment of Burns / Henry E. Sigerist // Bulletin of the History of Medicine. - February 1944. - 15, № 2. 214.

42 Billroth Th. Historical Studies. - P. 142.
} 


\section{Додаток E}

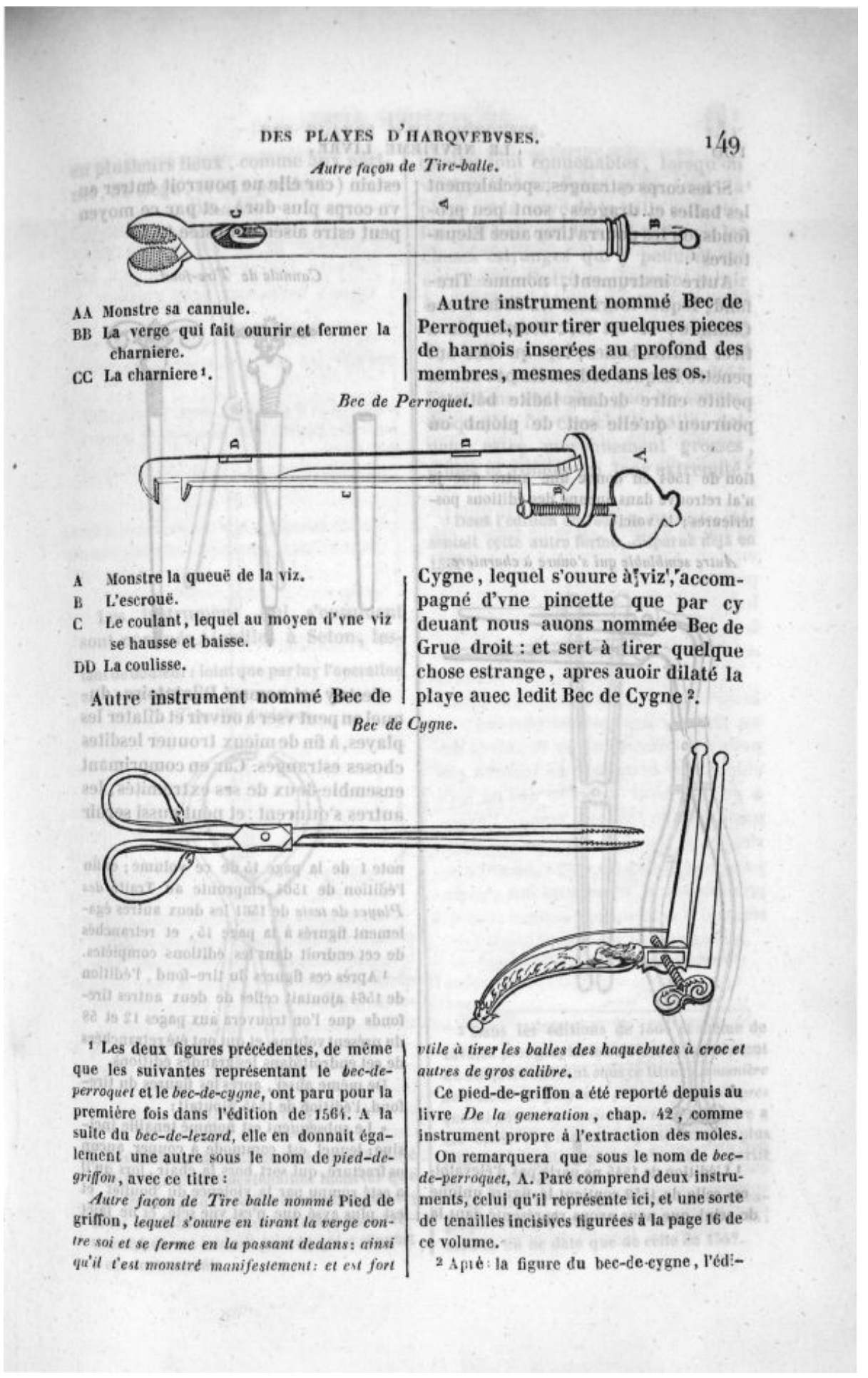

Хірургічний інструмент Амбруаза Паре «Вес de perroquet».

Взято 3: Malgaigne, J. F. Oeuvres complètes d'Ambroise Paré, revues et collationnées sur toutes les éditions, avec les variantes / J.F. Malgaigne. - A Paris, chez J.-B. Baillière, 1840-1841.

У той же час, хірурги Теодор де Лука, Генрі де Мондевіль, Гюї де 
Шоліак, Леонардо Боталло, Альфонсіо Ферріо, Абруаз Паре та інші значно випередили свою епоху, а тому отриманих знань їм було замало: усю свою подальшу діяльність вони спрямовували на перевірку давніх теорій, їхнє вдосконалення та створення нових учень. Їхні напрацювання активно використовувалися лікарями та військами у наступні століття та навіть у часи Другої світової війни (!), коли практичне застосування знайшли способи обробки опіків Амбруаза Паре.

Хоча, 3 сучасної точки зору, способи лікування ран в епоху Середньовіччя та раннього Відродження здаються нелогічними та безглуздими, проте практичні дослідження доводять, що багато ліків того періоду справді мали цілющий ефект, тому певні поради можуть бути корисними навіть сучасним хірургам.

\section{MA in History Oksana Obukhovs'ka (Lviv, Ukraine)}

Wounds and methods for their treatment in the Middle Ages and early Renaissance

The article analyzes the main methods and substances that were used to treat wounds in the Middle Ages and subsequent centuries. The author pays special attention to methods of treating combat wounds caused by arrows and firearms. A modern view is also given of the appropriateness and harm of such medicine.

Key words: Wound, History of Medicine, Middle Ages, Firearms.

магистр Оксана Обуховская (Львов, Украина)

\section{Раны и способы их лечения в эпоху средневековья и раннего Возрождения}

В статье проанализированы основные методы и вещества, которые использовались для лечения ран в Средние века и в последующие столетия. Особое внимание автор обращает на способы лечения боевых ран, вызванных стрелами и огнестрельным оружием. Подается и современный взгляд на целесообразность и вред от подобной медицины.

Ключевые слова: рана, история медицины Средневековья, огнестрельное оружие.

магістр Оксана Обуховська (Львів, Україна)

Рани та способи їхннього лікування в епоху середньовіччя та раннього Відродження

У статті проаналізовано основні методи та речовини, які використовувалися для лікування ран у Середні віки та протягом наступних століть. Особливу увагу авторка звертає на способи лікування бойових ран, викликаних стрілами та вогнепальною зброєю. Подається і сучасний погляд на доцільність та шкоду від подібних медичних втручань.

Ключові слова: рана, історія медицини, середньовіччя, вогнепальна зброя. 
Аннали юридичної історіï. 2020. Том 4. Випуск 1

* Обуховська Оксана Святославівна - магістр історії історичного факультету Львівського національного університеті імені Івана Франка.

E-mail: vlad.kiorsak@gmail.com. 